Portland State University

PDXScholar

9-18-1974

\title{
Characterization of Zinc-containing Metalloproteins by Resonance Raman Spectroscopy
}

\author{
Robert Edward Derry
}

Portland State University

Follow this and additional works at: https://pdxscholar.library.pdx.edu/open_access_etds

Part of the Chemistry Commons

Let us know how access to this document benefits you.

\section{Recommended Citation}

Derry, Robert Edward, "Characterization of Zinc-containing Metalloproteins by Resonance Raman Spectroscopy" (1974). Dissertations and Theses. Paper 2167.

https://doi.org/10.15760/etd.2164

This Thesis is brought to you for free and open access. It has been accepted for inclusion in Dissertations and Theses by an authorized administrator of PDXScholar. Please contact us if we can make this document more accessible: pdxscholar@pdx.edu. 
AN ABSTRACT OF THE THESIS OF Robert Edward Derry for the Master of Science in Chemistry presented September 18, 1974.

Title: Characterization of Zinc-Containing Metalloproteins by Resonance Raman Spectroscopy.

APPROVED BY MEMBERS OF THE THESIS COMMITTEE:

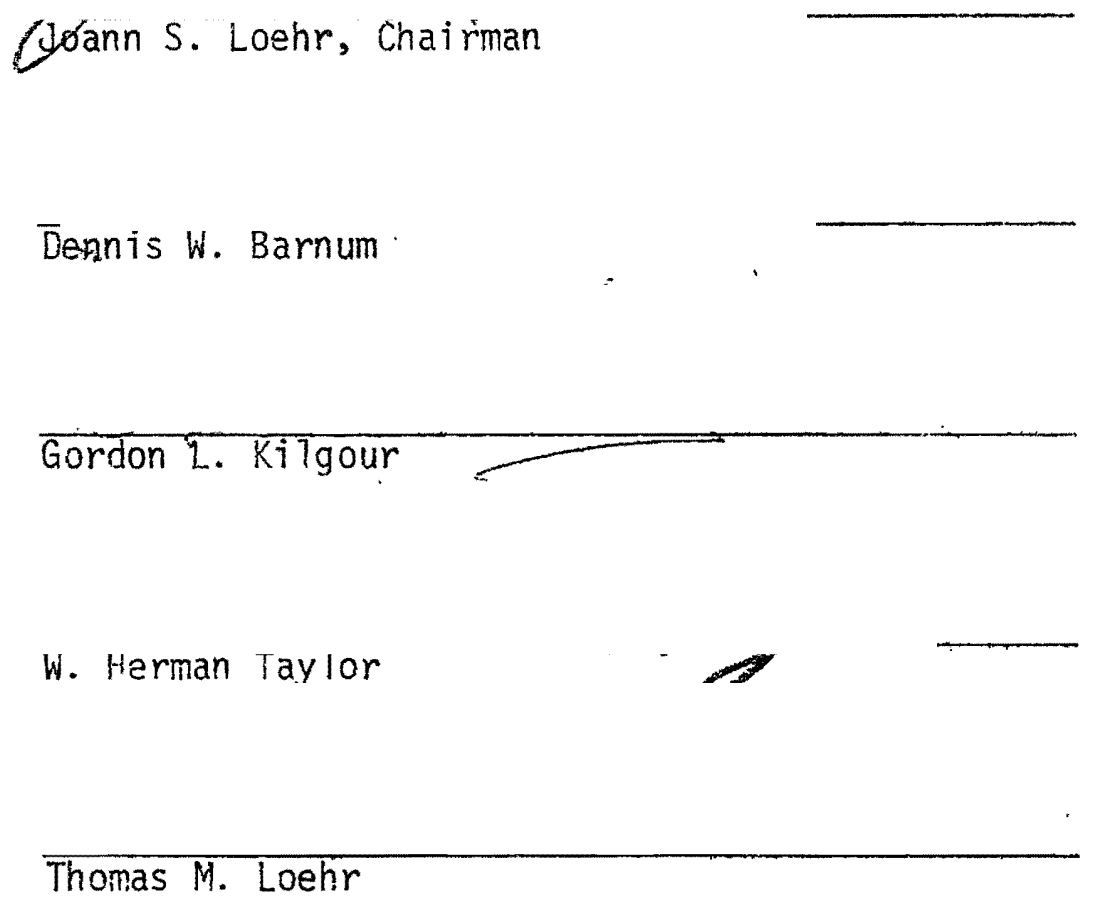

Thomas M. Loehr

Cobalt-substifuted carboxypeptidase and carbonic anhydrase were chosen as candidates for resonance Raman spectroscopy because they possess visible absorption due to the Co(II)-protein complex. However, no evidence for resonance-enhanced peaks due to the cobalt-containing chromophore was found with laser excitation near the visible absorption bands $(514.5 \mathrm{~nm})$ or closer to the ultraviolet absorption bands $(457.9 \mathrm{~nm})$. 
Arsanilazocarboxypeptidase and model azotyrosine compounds were selected for a Raman spectroscopic investigation because they have intense absorption bands in the visible region. All of these substances yielded similar resonance Raman spectra. Although there was no evidence for specific zinc-ligand vibrations, shifts in vibrational frequencies of the azotyrosine chromophore could be used as proof of zinc complexation. The protonated azotyrosine model compound was found to have the phenoxy group hydrogen bonded to the azo group, forming a six-membered ring. Replacement of the proton by zinc resulted in the zinc atom being bound only to the phenoxy group. In arsanilazocarboxypeptidase the azotyrosine at position 248 in the polypeptide chain was found to have a structure similar to the protonated model compound, a six-membered ring with zinc bridging the phenoxy group and the azo group. This gave further proof that Tyr 248 is close to the zinc atom in the native enzyme, even in the absence of substrate. 
CHARACTERIZATION OF ZINC-CONTAINING NETALIOPROTEINS BY RESONANCE RAMAN SPECTROSCOPY

$$
\text { by }
$$

ROBERT EDWARD DERAY
A thesis submitted in partial fulfillnent of the requirements for the degree of

MASTER OF SCIENCE

in

CHEMISTRY

Portland State University

1974 
TO THE OFFICE OF GRADUATE STUDIES AND RESEARCH:

The members of the Committee approve the thesis of Robert Edward Derry presented 18 September, 1974.

Joann S. Loehr', Cha irman

Dennis W. Barnum

Goréton K. Ki lgour

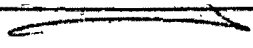

W. Herman Taylor

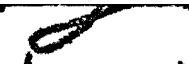

Thomas M. Loehr

APPROVED:

Gary L. Gard, Head, Department of Chemistry

Dávid 1. Clark, Dean of Graduate Studies and Research 


\section{ACKNOWLEDGEMENTS}

I would like to gratefully acknowledge the excellent assistance and time of Dr. J. Loehr, Dr. T. Loehr, Dr. C. Yoshida, Dr. T. B. Freeman, and Dr. R. Lutz. This work was supported by a grant to Dr. J. Loehr from the Research Corporation. 


\section{TABLE OF CONTEENTS}

\section{PAGE}

ACKNOWLEDGEMENTS

INTRODUCTION 1

Raman Spectroscopy 2

Resonance Raman Spectroscopy 3

MATERIALS AND MEMHODS 7

Materials ?

Enzynie Assays $\quad \cdots$

Protein Concentration $\quad 8$

Preparation of Cobalt Enzymes 4

Preparation of Diazoarsanilic Acid 9

Preparation of Arsanilazotyrosine (Ars-AzoTyr) 10

Preparation of Arsanilazocarboxypeptidase (Ars-AzoCP) 10

Preparation of 5-Diazo-IH-tetrazole (DHT) 11

Preparation of Tetrazolylazo-N-carbobenzoxytyrosine (Tetr-AzoTyr) II

Atomic Absorption Spectroscopy 11

UItraviolet/Visible Spectroscopy 12

Raman Spectroscopy 12

RESULTS 13

Properties of Cobalt-Substituted Zinc Enzymes 13

Raman Spectra of Cobalt-Substituted Zinc Enzymes 14 
Properties of Azotyrosine-Containing Compounds and Arsanilazocarboxypeptidase $\quad 16$

Paman Spectra of Azotyrosine Cokpounds $\quad 19$

Ramen Spectra of Arsanilazocarboxypeptidase 26

DISCUSSION

Cobalt-Substituted Enzymes 31

Azotyrosine Compounds 32

Arsanilazocarboxypeptidase $\quad 34$

REARENCES 


\section{LIST OF TABLES}

TABLE

PAGE

I Properties of Cobalt-Substituted Enzymes

II Raman Spectra of Carbonic Anhydrase and Lysozyme

III Spectral Properties of Ars-AzoTyr and Tetr-AzoTyr 17

IV Spectral Properties of Ars-AzacP 17

V Properties of Ars-AzoCP Preparations 18

VI Raman Spectral Frequenctes of Tyrosine and Arsanilic Acid 20

VII Principal Raman Spectral Exequencies of Ars-AzoTyr, . $\quad 22$ Tetr-AzoTyr, and $N^{15}$-Tetr-AzoTyr

VIII Raman Spectral Frequencies of DHT and Tetr-AzoTyr 24

IX Intensities of Selected Raman Frequencies of Azo Compounds 25 as a Function of Excitation Iine

$X$ Raman Spectral Frequencles of Ars-AzoCP and $\mathrm{N}^{15}$-Ars-AzoCP 30 


\section{LIST OF FIGURES}

FIGURE

PAGE

1. Azo Derivatives of Tyrosine and Related Compounds 6

2. Raman Spectrum of Zn(II)-Tetr-AzoTyx (pH 9) 27

3. Raman Spectrua of $\mathrm{N}^{15}$-Ars-AzoCP ( $\left.\mathrm{pH} 8.8\right)$

4. Proposed Mechanisin of Action of Carboxypeptidaso 37 


\section{INTRODUCTION}

Of the many zinc containing enzymes, two are of special interest because their three dimensional structures are known. These enzymes are carbonic anhydrase and carboxypeptidase.

Carbonic anhydrase catalyses the hydration of carbon dioxide, which is of great physiological importance to animals:

$$
\mathrm{CO}_{2}+\mathrm{H}_{2} \mathrm{O} \rightleftarrows \mathrm{HCO}_{3}^{-}+\mathrm{H}^{+}
$$

The enzyme has a molecular weight of 30,000 , and it has one polypeptide chain and one zinc aton per molecule (1).

Carboxypeptidase aids in the digestion of proteins in the small intestine of animals. This enzyme hydrolyzes the carboxy terminal peptide bond in proteins:

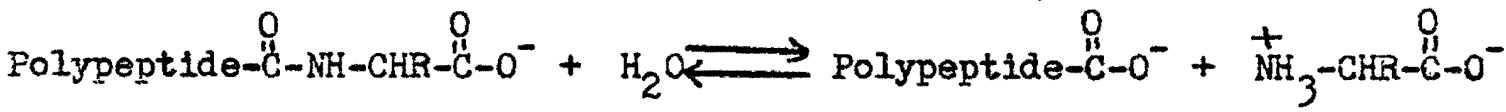

The enzyme has a molecular weight of 34,600 , and it has one polypeptide chain and one zine atom per molecule (1).

The zinc atom is essential for these enzymes to function normally. Removal of the zinc atoms results in these enzymes becoming inactive; both of these enzymes can be restored to activity by the addition of zinc or cobalt (2).

The active sites of both of these enzymes have been determined by 
X-ray crystallography. Carbonic anhydrase has zinc in a distorted tetrahedron in which it is bonded to imidazole nitrogens of His-93, His-95 and His-1I7, and one water molecule (3). Carboxypeptidase, also, has zinc bonded to four 11gands, which are imidazole nitrogens of His-196 and His-69, carboxylate oxygen of Glu-72, and one water molecule when the enzyme is in the crystalline state (4).

Although the crystal stmctures are known, the structures of the enzymes in solution have not been determined. The structure of an enzyme in the crystalline state may not be identical to the structure of the biologically active form in solution. For this reason, we used vibcational spectroscopy, particularly resonance Raman spectroscopy to observe the structure of the active site of carbonic anhydrase and carboxypeptidase in solution.

\section{Raman Spectroscopy}

Raman spectroscopy, Iike infrared spectroscopy, detects energies of vibrational transitions. However, Raman spectroscopy is concerned with light inelastically scattered by molecules in its path, rather than radiation which is absorbed. In infrared spectroscopy, one sees absorptions due to vibrations involving a change in dipole moment; while in Raman spectroscopy, one sees scattering due to vibrations involving a change in polarizability (5).

Water molecules undergo large changes in bond dipole moments during their normal modes of vibration and are very strong absorbers of the infrared, but are poor scatterers in the Raman effect. Water, thus, produces relatively little interference in Raman studies in aqueous solutions. 
Resonance Raman Spectroscopy

Resonance Raman spectroscopy is a special form of Raman spectroscopy in which Raman spectral intensities are enhanced as a result of the coupling of electronic and vibrational transitions of a chromophore (6). Raman scattering intensity is inversely proportional to $\left(\mathrm{ye}^{2}-\mathrm{yo}^{2}\right)^{4}$ where $V_{e}$ is the frequency of the electronic transition and $\gamma_{0}$ is the frequency of incident radiation (7). Thus, as $V_{0}$ approaches $V_{e}$, the Raman intensity incresses. The resonance Raman spectrum is strongest when the wavelength of exciting light corresponds to an electronic absorption maximum of the chromophore and gets weaker as one goes away from this wavelength. Generally, lasers are used as light sources because they provide intense, monochromatic lines of various wavelengths.

Resonance Raman spectroscopy is an important tool for investigating metalloproteins that absorb light in the visible region. When the excitation wavelength falls in an electronic absorption band of the sample, then certain Raman bands can be greatly enhanced. These resonance Raman bands correspond to vibrational modes which involve motions of the atoms in the chromophore, that part of the nolecule in which the electronic transition occurs (6). The amount of vibrational structure observed in the resonance Raman effect depends on the extent of electron delocalization in the chromophore. Thus, one sees only the metal-ligand chromophore and not the rest of the protein molecule. An additional advantage of resonance Raman spectroscopy is that one only needs to use very Iow concentrations of the protein (often as low as $10^{-7}$ molar). Resonance Raman spectroscopy has been very useful in gaining information about metalloproteins. The heme groups of heme proteins give resonance Raman spectra in which the porphyrin ring vibrations are 
enhanced. Studies of heme-iron proteins indicate that certain Raman bands are sensitive to either or both the valence and spin state of the iron ( 8 , 9). The frequency of the strongest band in the spectra for reduced hemeproteins occurs between 1356 and $1361 \mathrm{~cm}^{-1}$, whereas for oxidized proteins it occurs between 1370 and $1378 \mathrm{~cm}^{-1}$. Chemical modifications of heme proteins resulting in the conversion of iron from a low spin state to a high spin state have been correlated with a 1584 to $1566 \mathrm{~cm}^{-1}$ frequency shift, which is independent of oxidation state and which is ascribed to the movement of the iron atom out of the heme plane upon increasing its spin state. Oxyhemoglobin has its strongest peaks at 1375 and $1584 \mathrm{~cm}^{-1}$ and has thus been identifled as a lou spin ferric structure (8).

The resonance Raman spectrum of hemocyanin has provided evidence about the binding of oxygen to the active site copper. Upon oxygenation, hemocyanin gives a resonance Raman peak at $742 \mathrm{~cm}^{-1}$, and this peak shifts to $704 \mathrm{~cm}^{-1}$ when ${ }^{18} \mathrm{O}_{2}$ is substituted for ${ }^{16} \mathrm{O}_{2}$. The frequency of the 0-0 vibration is most characteristic of a peroxide-containing molecule in a non-aqueous environment (738 $\mathrm{cm}^{-1}$ for $\mathrm{Na}_{2} \mathrm{O}_{2}$ as a solid) (10).

Resonance Raman spectra have also provided evidence about the coordination of the netal ion at the active site of metalloproteins. The resonance spectrum of rubredoxin has shown that the tetrahedral coordination about the iron atom in the crystalline state appears to be maintained in solution (11).

While zinc containing carboxypeptidase and carbonic anhydrase have no chromophores in the visible region, cobelt substituted carboxypeptidase and carbonic anhydrase do have visible absorptions due to the Co(II)-protein complex $(12,13)$. It was conjectured that the cobalt chromophores of these enzymes might give resonance Raman spectra. From 
this one could gain evidence about the structure of the active sites of these enzymes.

Carboxypeptidase can be modified by reaction with an azo reagent to make a derivative in which tyxosine at the active site (Tyr-248) is modified to an azotyrosine (14). This results in a chromophore with an intense absorption in the visible region. The modified carboxypeptidase has a yellow color in the crystalline state, but turns red upon going into solution (15). This is due to a change in the electronic composition of the chromophore. In the crystaline state, azotyrosine-248 is protonated at $\mathrm{pH}$ 8.2. When the nodified enryme is dissolved, azotyrosine-248 loses its proton and complexes with zinc. If one removes the zinc atom, the modifled enzyme turns yellow in solution because azotyrosine-248 becomes protonated. Thus, carboxypept1dase appears to have a different structure in the crystalline state and in solution. In the crystalline state, the tyrosine near the active site (Tyx-248) has Its hydroxyl group pointed away from the active site zinc, and toward the hydrophtlic exterior (4). It has been proposed (15) that the tyrosine248 swings in toward the zinc and its hydroxyl group forms a bond to the zinc when the enzyme goes into solution. With resonance Raman spectroscopy, one might gain information about the active site of carboxypeptidase in solution.

For these reasons, we decided to investigate chronophore containIng dertvatives of zinc enzymes by resonance Raman spectroscopy. These include cobalt carboxypeptidase, cobalt carbonic anhydrase, and azo derivatives of carboxypeptidase and model tyrosine compounds. Structures for the azo compounds are shown in Figure 1. 
<smiles>COc1ccc(N)cc1</smiles>

Arsanilie Acld

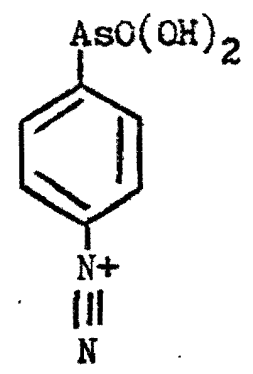

Dlazoarsanilic Acid<smiles>NC(Cc1ccc(O)c(N=Nc2ccc([S+](=O)O[OH2+])cc2)c1)C(=O)O</smiles>

Arsanilazotyrosine (Ars-AzoTyr)<smiles></smiles><smiles>[Y5]#[N+]c1nnnn1[Tl]</smiles>

5-Amino-IH-tetrazole<smiles></smiles>

Tetrazolylazo-N-carbobenzoxytyxosine (Tetr-AzoTyx)

Figure I. Azo derivatives of tyrosine and related compounds (N15 designates position of $N^{15}$ substitution). 
MATERIAIS AND METHODS

\section{Materials}

A11 the reagents were Reagent grade. Hippuryl-L-phenylalanine and p-arsanilic acid were obtained through Sigma Chemical Company. 5amino-IH-tetrazole was obtained from J. T. Baker Chemlcal Company. $\mathrm{NaNO}_{2}, \mathrm{ZnSO}_{4}, \mathrm{CoCl}_{2}$, and ortho-phenanthroline were obtained from Mallinckrodt Chemical Works. Tris (hydroxy methyl) amino methane (Enzyme and Buffer grade) and $\mathrm{N}$-carbobenzoxy -L-tyrosine were obtained from Schwarz/Mann. The cobalt and zinc atomic absorption standards were obtained from Fisher. $\mathrm{NaN}^{15} \mathrm{O}_{2}\left(97 \% \mathrm{~N}^{15}\right)$ was obtained from Stohler Isotope Chemicals.

Carboxypeptidase was obtained from Sigma Chemical Company and Worthington Blochemical Corporation. Although the source of both of these enzymes was the same (bovine pancreas), these two enzymes were different forms of carboxypeptidase $\mathrm{A}$ as a result of different methods of purification. The Worthington carboxypeptidase, the $\gamma_{\text {form, }}$ is the less soluble form (16) and it was used in the preparation of arsanilazocarboxypeptidase. The Sigma carboxypeptidase, the fform (17), was used to make cobelt carboxypeptidase. The $\gamma$ and $\delta$ forms aiffer in the number of $\mathrm{C}$-terminal amino acids removed in converting the zymogen, procarboxypeptidase, to active enzyme. They differ in their solubilities but show the same pattern of structural differences between crystal and soIution as determined from the color of the azo enzymes (18). Carbonic anhydrase was obtalned from S1gma Chemlcal Company. The 
source of the enzyme was bovine erythrocytes.

\section{Enzyme Assays}

Carboxypeptidase activity was determined by the rate of hydrolysis of the substrate hippuryl-I-phenylalanine as measured by the increase in absorbance at $254 \mathrm{~nm}$ at room temperature. The substrate was allowed to พarm up to room temperature before addition of the enryme. A unit of activity is equal to one micromole of hippuric acid $\left(\epsilon_{\mathrm{ml}}=0.36\right.$ ) hydrolyzed per minute (19). Specific conditions were substrate concentration of $0.001 \mathrm{M}, \mathrm{pH} 7.5$ buffer of $0.025 \mathrm{M} \mathrm{Tris}$ with $0.5 \mathrm{M} \mathrm{NaCl}$, and an enzyme concentration of $1-10 \mu \mathrm{g} / \mathrm{m}$.

Carbonic anhydrase activity was measured by the rate of production of hydrogen ions (20). The time in seconds required for a saturated $\mathrm{CO}_{2}$ solution to lower the $\mathrm{pH}$ of 0.012 molar veronal buffer fron 8.3 to 6.3 was determined. Activity is proportional to " $\mathrm{T}_{0}-\mathrm{T}$ " where " $\mathrm{T}_{0}$ " is the time without the enzyme and "T" is the time with the enzyme.

\section{Protein Concentration}

The concentration of carboxypeptidase was determined using the optical density of a $0.1 \%$ solution as 1.94 at $278 \mathrm{~nm}$ (21). The concentration of carbonic anhydrase was determined using the optical density of a $0.1 \%$ solution as 1.80 at $280 \mathrm{~nm}(22)$.

\section{Preparation of Cobalt Enzymes}

To minimize trace metal contamination, all glassware was cleaned with a $\mathrm{I} / \mathrm{I}$ mixture of concentrated $\mathrm{HNO}_{3}$ and $\mathrm{H}_{2} \mathrm{SO}_{4}$, and then rinsed ten times with tap water and distilled water.

Cobalt carbonic anhydrase was prepared using a modification of the 
procedure described by Coleman (23). The encyme, 5-30 mg/ml, was depleted of zine by dialysis against $0.01 \mathrm{M}$ acetate buffer (pH 5.5) containing $4 \times 10^{-3} \mathrm{M}$ ortho-phenanthroline for a period of two weeks with changes of dialysis solution every two days. The enzyme was then dialyzed against distilled water for one day to remove traces of oxtho-phenanthroIine (which forms a colored complex with cobalt), then against $0.025 \mathrm{M}$ Tris-cl ( $\mathrm{pH} 7.0$ ) containing $0.001 \mathrm{M} \mathrm{CoCl}_{2}$ for one day, then against 0.01 M Tris-CI (pH 7.0) for one day to remove excess cobalt, and lastly against $0.005 \mathrm{M}$ Tris-cl ( $\mathrm{pH}$ 8.5), which is the optimal pH for color formation (24). The dialysis solutions contained $100 \mathrm{ml}$ of solution per ml of enzyme solution.

Cobalt carboxypeptidase was made using a modification to the method of Vallee et al. (25). The enzyme solution, $5 \mathrm{mg} / \mathrm{ml}$, was dialyzed against $0.1 \mathrm{M}$ Tris-Cl ( $\mathrm{pH} 7.0)$ containing $1 \mathrm{M} \mathrm{NaCl}$ and $2 \times 10^{-3} \mathrm{M}$ orthophenanthroline for a period of two days. The dialysis solution was changed to water for one day to remove traces of ortho-phenanthroline, and was then changed to $0.1 \mathrm{M} \mathrm{Tris-CI}\left(\mathrm{pH} 7.0\right.$ ) containing $1 \times 10^{-3} \mathrm{M} \mathrm{CoCI}_{2}$ and I M NaCl for one day. Next, the enzyme was dialyzed against $0.1 \mathrm{M}$ Tris-CI ( $\mathrm{pH} 7.0$ ) containing I M NaCI for one day, and the solution was changed twice.

Cobalt and zinc carbonic anhydrase solutions were concentrated using an Amicon ultrafiltration cell (model 52) with an Amicon PM-10 membrane, which excludes proteins with molecular weights above 15,000. Preparation of Diazoarsanilic Acid

The diazonium salt of arsanilic acid was prepared from arsanilic actd and $\mathrm{NaNO}_{2}$ as described by Fairclough and Vallee (26) with the 
following modifications: $\mathrm{NaBr}(0.2$ moles per mole of arsanilic acti) was added at the start of the reaction to prevent self-coupling of arsanilic acid and to catalyze the reaction (27). Also, the pH of the inixture was adjusted to 6.5-7.0 instead of 5.0-5.5 in order to improve the specificity of the diazotization reaction (personal communication from Ivan Iegg).

\section{Preparation of Arsanilazotyrosine (Ars-AzoTyr)}

One hundred $\mathrm{ml}$ of $2 \times 10^{-4} \mathrm{M}$ tyrosine dissolved in $I \mathrm{M} \mathrm{NaOH}$ ( $\mathrm{pH} I 1$ ) was reacted with $0.05 \mathrm{ml}$ of $0.02 \mathrm{M}$ diazoarsanilic acid in an ice bath. The reaction was vexy rapid and went to completion as judged by formation of a colored product with maximum absorbance at $485 \mathrm{~nm}$.

\section{Preparation of Arsanilazocarboxypeptidase (Ars-AzoCP)}

Arsanilazocarboxypeptidase was prepared using a modification to the method of Johansen and Vallee (15). The crystalline carboxypeptidase (40-50 mg) was washed once by suspension in distilled water, centrifuged in a Sorvall centrifuge (10 $\mathrm{min}$, at $12,000 \times \mathrm{g}$ ), and then suspended in $18 \mathrm{ml}$ of distilled water. To this solution were added $3 \mathrm{ml}$ of $0.02 \mathrm{M}$ diazoarsantlic actd and $0.3 \mathrm{ml}$ of $0.11 \mathrm{M} \mathrm{NaHCO}_{3}$. The pH was quickly adjusted to 8.5 with $0.1 \mathrm{M} \mathrm{NaOH}$ and then to 8.7 with $0.01 \mathrm{M} \mathrm{NaOH}$. The mixture was continually adjusted to pH 8.7 for 10 minutes and then left in an ice bath for about two hours. (Note that the pH meter was standardized at room temperature, although $\mathrm{pH}$ measurements were made at low temperature.) The crystals were then centrifuged as above and washed twice with $0.05 \mathrm{M}$ phosphate buffer ( $\mathrm{pH} 7.0$ ) to stop side reactions by lowering the $\mathrm{pH}$, followed by a final washing with water. The crystals were dissolved in $5 \mathrm{M} \mathrm{NaCl}$ and then dialyzed versus buffer containing 2 $\mathrm{M}$ NaCl to the desired $\mathrm{pH}\left(0.05 \mathrm{M} \mathrm{NaHCO}_{3}\right.$ for $\mathrm{pH} 11.5,0.05 \mathrm{M}$ Pris-CI for 
pH 8.8). The solution of modified enzyme was concentrated by ultrafiltration using an Amicon ultrafiltration cell (model 52) with a PM 10 membrane.

The concentration of the modified enzyme was estimated by the absorbance at $278 \mathrm{~nm}$ using an extinction coefficient of $7.32 \times 10^{4} \mathrm{M}^{-1} \mathrm{~cm}^{-1}$ (28).

Preparation of 5-Diazo-1H-tetrazole (DHT)

The preparation of 5-diazo-IH-tetrazole was done using a modification to the method of Sokolovsky and vallee (29). Care must be taken to use cold solutions and low concentrations when making this reagent since it is highly explosive. Ice cald $10 \% \mathrm{NaNO}_{2}(0.7 \mathrm{ml})$ was added slowly with stirring over a period of 5 minutes to 0.1 grams of 5-amino$1 H$-tetrazole dissolved in $3.3 \mathrm{ml}$ of lce cold $2 \mathrm{M} \mathrm{HCl}$. After 10 minutes, the $\mathrm{pH}$ was adjusted to 5.0-6.0 and 1ce cold water Has added to give a final volume of $100 \mathrm{ml}$.

Preparation of Tetrazolylazo-N-carbobenzoxytyrosine (Tetr-AzoTyr)

Three $\mathrm{ml}$ of $0.01 \mathrm{M} \mathrm{5-diazo-IH-tetrazole} \mathrm{were} \mathrm{combined} \mathrm{with} 30 \mathrm{ml}$ of $2 \times 10^{-3} \mathrm{M} \mathrm{N}$-carbobenzoxy-L-tyrosine (pH 9.0) and $67 \mathrm{ml}$ of water and left at room temperature for 30 minutes (29).

The metal complexes of Tetr-AzoTyx were made using a $1 / 1$ molar rat10 of Tetr-AzoTyr ( $\mathrm{pH} 9.0)$ and $\mathrm{ZnCl}_{2}, \mathrm{Cd}\left(\mathrm{NO}_{3}\right)_{2}$, or $\mathrm{Hg}\left(\mathrm{NO}_{3}\right)_{2}, \mathrm{Hg}\left(\mathrm{NO}_{3}\right)_{2}$ had dissolved only in acid solution. Final pH (ca. 8.5) for the mercury complex was determined by maximum color formation.

\section{Atonic Absorption Spectroscopy}

Atomic absorption values were obtained with a Varian-Techtron AA-5 
Atomic Absorption Spectrophotometer. Enzymes were run at 0.2 to $0.5 \mathrm{mg} /$ $\mathrm{ml}$ and the standards were mun at 5 to 50 micromolar.

\section{Ultraviolet/visible Spectroscopy}

Ultraviolet and visible spectra and aseay kinetics were taken on a Cary 14 Recording Spectrophotometer.

\section{Raman Spectroscopy}

Raman spectra were obtained with a Jarrell-Ash 25-300 Raman Spectrophotometer using either a Coherent Radiation Laboratories model 52 srgon ion laser $(514.5,488.0$, and $457.9 \mathrm{~nm}$ ) or a Spectra-Physics model 125 helium-neon laser $(632.8 \mathrm{~nm})$. Neutral density filters $(20 \%-50 \%)$ were used with protein samples to attenuate the laser porer so that the sample would not boil. $\mathrm{K}_{2} \mathrm{SO}_{4}$ was added as an internal standard. The concentration of $\mathrm{K}_{2} \mathrm{SO}_{4}$ was generally $0.5 \mathrm{M}$. 


\section{RESULTS}

Properties of Cobalt-Substituted Zinc Enzymes

The results of cobalt substitution for carboxypeptidase (CP) and carbontc anhydrase (CA) are shown in Table I. The zinc atom of carboxypeptidase was readily removed and replaced with cobalt. After 17 hours, $74 \%$ of the zinc was removed fron carboxypeptidase. Carbonic anhydrase releases its zinc atoms much less readily. After one week, only $47 \%$ of the zinc was removed from cartonic anhydrase. After two days for carboxypeptidase, and two weeks for carbonic anhydrase, almost all of the zinc atoms had been removed. Reconstitution with cobalt was complete in both cases although carbonic anhydrase contained excess cokalt. This was later corrected by including the pH 7.0 rinse to remove cobalt prior to raising the $\mathrm{pH}$ to 8.5 (see Matexials and Methods). At pH 8.5, excess $C o(I I)$ is oxidized to $C o($ III) which binds more strongly to the protein. The relative activities of the cobalt and zinc enzymes agree with those of other workers. Cobalt carboxypeptidase with a relative activity of $144 \%$ is very close to the value of $150 \%$ reported by vallee et a. (25). Cobalt carbonic anhydrase with a relative activity of $50 \%$ is quite similar to the reported value of $45 \%(30)$. 
TABLE I

PROPERTIES OF COBALT-SUBSTITUTED ENZMES

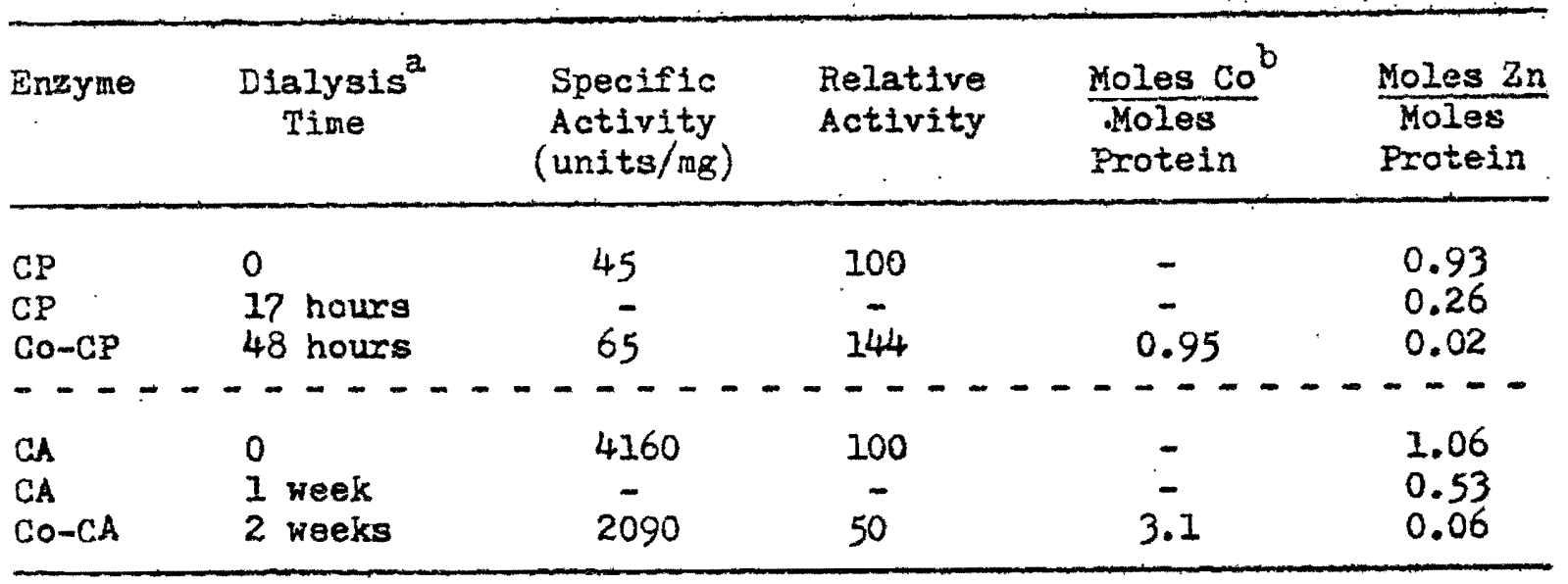

a. Dialysis versus ortho-phenanthroline to remove zinc.

b. Excess cobalt bound to carbonic anhydrase moleculo could be removed by more extensive dialysis versus .01 M Tris-cl (pH 7.0).

\section{Raman Spectra of Cobalt-Substituted Zinc Envymes}

Raman spectroscopy was performed with excitation at $457.9,488.0$ and $514.5 \mathrm{~nm}$. The latter two Iines were chosen because they most closely correspond to the visible absorption maxima observed for cobalt-substituted proteins between 520 and $560 \mathrm{~nm}(2)$. Since the molar absorptivities of cobalt-substituted enzymes are only 200-300 1iter mole $\mathrm{cm}^{-1}$ (2), it was not possible to obtain resonance Raman spectra for either enzyme at concentrations up to $15 \mathrm{mg} / \mathrm{ml}\left(\mathrm{A}_{510}-0.1\right)$. Very high concentrations of cobalt and zinc carbonic anhydrase $(43-75 \mathrm{mg} / \mathrm{ml})$ did produce Raman spectra. However, there was no indication of resonance-enhanced peaks as the spectra of the zinc and cobalt enrymes were identical. This can also be seen from Table II in whlch the Raman spectrum of cobalt carbonic anhydrase is compared with that of Iysozyme (31). The peaks of the cobalt carbonic anhydrase spectrum can all be assigned by comparison 
TABLE II

RAMAN SPECTRA OF GARBONIC ANHYDRASE AND LYSOZYME

\begin{tabular}{|c|c|c|c|c|}
\hline Frea & $\left(\mathrm{cm}^{-1}\right)$ & & Tentative Assignment & \\
\hline CoCA ${ }^{a}$ & Iysozyme ${ }^{b}$ & & . & \\
\hline 420 & $429(2)$ & & & \\
\hline 480 & $491(0)$ & & & \\
\hline - & $509(5)$ & & S-S stretch & \\
\hline 550 & 544 (1) & & $\operatorname{Trp}$ & \\
\hline 645 & $646(0)$ & & Tyx & \\
\hline 756 (s) & 761 (10) & & $\operatorname{Trp}$ & \\
\hline 830 & 836 (1) & & Tyx & \\
\hline $880(\mathrm{~s})$ & $879(5)$ & & $\operatorname{Trp}$ & \\
\hline 960 & $964(0)$ & & & \\
\hline 1005 (s) & 1006. (7) & & Phe & · \\
\hline 1075 & 1078 (1) & . & C-N stretch & \\
\hline 1125 & 1128 (3) & & C-N stretch & \\
\hline 1205 & $1210(2)$ & & Tyr \& Phe & \\
\hline 1235 & $1240(4)$ & . & Anlde III & \\
\hline $1258(\mathrm{~s})$ & $1262(5)$ & & Amide III & \\
\hline $1340(\mathrm{~s})$ & $1338(8)$ & & $\operatorname{Trp}$ & \\
\hline $1450(s)$ & $1448(9)$ & & $C-H$ deformation & \\
\hline 1550 (s) & $1553(8)$ & & $\operatorname{mpp}$ & \\
\hline
\end{tabular}

a. Excitation at $514.5 \mathrm{~nm}$. (s) signifies a strong peak. Frequencles are in $\mathrm{cm}^{-1}$.

b., c. The values and assignments for lysozyme were obtained from Iord and $Y u(31)$. The numbers "0-10" represent a relative intensity scale with " 10 " as the maximum peak height. 
to Iysozyme, and one observes that the whole carbonic anhydrase protein molecule is involved with no evidence for the cobalt-containing chromophore. Iysozyme has four disulfide bonds, which give rise to the moderately strong peak at $509 \mathrm{~cm}^{-1}$ in the Raman, while cobalt carbonic anhydrase has no peak at this frequency. This agrees with the amino acid analysts of bovine carbonic anhydrase in which it was found that the enzyme lacks cysteine (32).

Properties of Azotyrosine-Containing Compounds and Arsanilazocarboxy peptidase

The spectral characteristics of arsanilazotyrosine (Ars-AzoTyr), tetrazolylazo-N-carbobenzoxytyrosine (Tetr-AzoTyr), and arsanilazocarboxypeptidzse (Ars-AzOCP) are shown in Tables III and IV. The spectral similarity of the azotyrosine derivatives to Ars-AzocP has led to their choice as models for the active site tyrosine of arsanilazocarboxypeptidase (15). Since Ars-AzoTyr precipitates upon complexation with metal ions, it was necessary to use the more soluble complexes of TetrAzoTyr as models for the zinc-containing Ars-AzocP. The formation of a red-colored complex in the presence of metal ions between $\mathrm{pH} 8.0$ and $\mathrm{pH}$ 9.0 has been considered indicative of complex formation between the metal Ion and the azophenolate molety (18).

In the diazotization of carboxypeptidase, tyrosine was the only residue to undergo significant modification (Table V). However, we were not able to reproduce the literature values for the extent of the modification or the specificity of the reaction with Myr-248. The modified enzyme had about $90 \%$ of the activity of the native enzyme, indicating that the apparent lack of reaction with Tyr-248 might be partly due to 
TABLE III

SPECTRAL PROPLRTIES OF ARS-AZOTYR AND TETR-AZCTYR

\begin{tabular}{|c|c|c|c|c|}
\hline Compound & $\mathrm{pH}$ & Color & $\lambda \max (n m)$ & Assignment \\
\hline \multirow[t]{2}{*}{ Ars-AzoTyr } & 5 & yellow & 400 & azophenol ${ }^{a}$ \\
\hline & 11 & orange & 480 & azophenolate ${ }^{a}$ \\
\hline \multirow[t]{2}{*}{ Tetr-AzoTyx } & --7 & yeilow & $---{ }_{400}^{-}$ & azophenol \\
\hline & 11 & orange & 480 & azophenolate? \\
\hline$\overline{\mathrm{Zn}}(\mathrm{II})-\mathrm{Tetr}-\mathrm{AzOTy}$ & 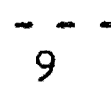 & - red $^{-}$ & $=-\frac{-}{510}$ & Zn-azophenolate \\
\hline $\mathrm{Hg}$ (II)-Tetr-AzoTyr & 9 & violet & 495 & Hg-azophenolate \\
\hline Cd(II)-Tetr-AzoTyr & 8.5 & pink & 485 & Cd-azophenolate \\
\hline
\end{tabular}

a. Tabachnick and Sobotka (27).

b. Johansen and Vallee (18).

TABLE IV

SPECTRAI PROPERTIES OF ARS-AZOCP

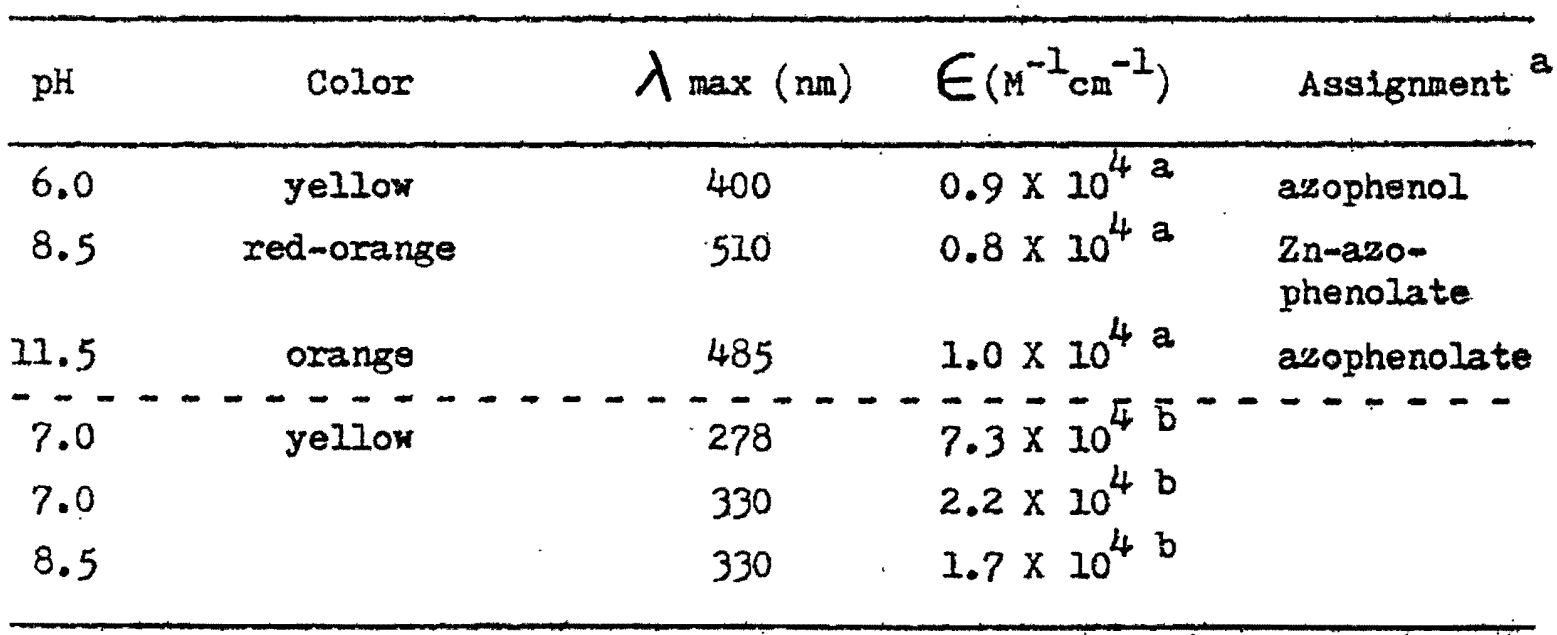

a. Johansen and Vallee (18).

b. Johansen et al. (28). 
TABIE $V$

PROPERTIES OF ARS-AZOCP PREPARATIONS

\begin{tabular}{lccc}
\hline Molar Ratios & This Iaborationy & Iiterature (Ref.) \\
\hline$\frac{\text { Azotyrosine }}{\text { Protein }}$ & $0.60^{\mathrm{a}}$ & 1.0 & (14) \\
$\frac{\text { Azohistidine }}{\text { Protein }}$ & $0.01^{\mathrm{b}}$ & 0.05 & $(14)$ \\
$\frac{\text { AzoTyx-248 }}{\text { Total Azotyrosine }}$ & $0.80^{\mathrm{c}}$ & 0.95 & (28) \\
\hline
\end{tabular}

a. [Azotyrosine] based on $A_{330}$, [protein] based on $A_{278}$, both at $\mathrm{pH} 7.0$.

b. Determined from $\mathrm{A}_{460}$ and $\mathrm{A}_{500}$ at $\mathrm{pH} 17.0$ according to the method of Tabachnicik and Sobotka (33). In their equation, $X$ is equal to the $\mu \mathrm{M}$ concentration of azohistidine and $Y$ is equal to the $\mu M$ concentration of azotyrosine.

$$
\begin{aligned}
& 16.50 X+9.60 Y=A_{460} \\
& 2.65 X+10.50 Y=A_{500}
\end{aligned}
$$

c. [Azotyrosine] rased on $\mathrm{A}_{330}$ at $\mathrm{pH} 8.5$. [AzoTyx-248] besed on $\mathrm{A}_{510}$ at $\mathrm{pH} 8.5$. 
denaturation. The best results were obtained by recrystallization of carboxypeptidase (34) prior to the reaction and careful control of pH during diazotization. However, we were not able to obtain a protein preparation in which more than $80 \%$ of the azotyrosines were complexed to the zinc atoms at $\mathrm{pH} 8.8$.

\section{Raman Spectra of Azotyrostne Compounds}

In Table VI, the Raman spectra of tyrosine ( $\mathrm{pH} 1.0$ ), tyrosine ( $\mathrm{pH}$ 11.0), and arsanilic acid are compared. There is very little change in the spectrum of tyrosine upon lonization. The major changes are in the ring modes (especially 1620-1604 $\mathrm{cm}^{-1}$ ) and the ring $\mathrm{CH}$ bends $(830-834$ $\mathrm{cm}^{-1}$ ). From this one can see that the spectrum is not really sensitive to the phenol ionization, with the possible exception of the appearance of the new bands at 1419 and $1336 \mathrm{~cm}^{-1}$.

The principal tyrosine 1ines, the $1600 \mathrm{~cm}^{-1}$ ring mode and the 816 $\mathrm{cm}^{-1}$ bend, are seen in the arsanilic acid spectrum. The $1096 \mathrm{~cm}^{-1}$ Iine can be assigned to the C-As vibration (35). Thus, arsanilic acid has the spectrum of a substituted benzene ring. However, these strong tyxosine and arsanilic acid lines do not appear in the resonance Raman spectrum of arsanilazotyrosine, although most of the Ars-AzoTyr lines appear to correspond to tyrosine lines:

TYR ( $\mathrm{pH} \mathrm{II)}$

$117 ?$

1212

1271

1362
ARS-AZOTYR (pH II)

1162

1200

1245

1338

The shifting of ring modes to lower frequencies is consistent with the electron withdrawing effect of an azo substituent on a benzene ring. The two major peaks of Ars-AzoTyr at 1385 and $1440 \mathrm{~cm}^{-1}$ cannot be 
TABIE VI

RAMAN SPECTRAL FREQUENCIES OF TYROSINE AND ARSANIIIC ACID ${ }^{a}$

Arsanilic Acld ${ }^{b} \quad$ Tyr $(\mathrm{pH} 11)^{c} \cdot \operatorname{Tyx}(\mathrm{OH} 1)^{\mathrm{d}} \quad$ Assiganent

$$
495 \text { (m) }
$$

$644(2) \quad 648(m)$

$816(10)$

$834(6)$

830 (s). Aromatic CH bend (e)

$854(4)$

850 (s). Ring mode (f)

$1096(5)$

C - As stretch (8)

1186 (1)

2177 (4)

2175 (m) Ring mode and OH bend (e)

1212 (6)

1212 (s) Ring mode and co stretch (f)

1276 (1)

$1271(5)$

$1270(\mathrm{~m})$

Ring node and co stretch

(h)

$1336(5)$

1362 (3) 1362 (m) $\quad$ Ring mode and $-\mathrm{CH}_{2}$-bend

$1419(3)$

1446 (3) $\quad 1449(\mathrm{u}) \quad-\mathrm{CH}_{2}$-bend (f)

1600 (4) $1604(10) \quad 1620$ (s) Ring mode (f)

a. Frequencies are in $\mathrm{cm}^{-1}$. Intensities are on 1 to 10 relative scale or noted as (s), strong; (m), medium; ( $w)$, weak.

b. Excitation at $632.8 \mathrm{~nm}$.

c. Excitation at $488.0 \mathrm{~nm}$.

d. Excitation at $488.0 \mathrm{~nm}$. No sulfate standard.

e. Pinchas et al. (36).

f. Jakobsen (37).

8. Pett1t and Turner (35).

h. PInchas (38). 
assigned to tyrosine since one would not expect to find the tyrosine $\mathrm{CH}_{2}$ vibrations ( 1449 and $1362 \mathrm{~cm}^{-1}$ ) in a resonance spectrum since the $\mathrm{CH}_{2}$ group is not part of the chromophore. Thus, there is very little correspondence between the tyrosine Raman spectral Iines and those in Axs-AzoTyr, and the main contribution to the chromophore and the source of resonance enhancement must be the azo group $(-\mathrm{N}=\mathrm{N}-)$.

The vibrations that give rise to the lines at 1385 and $1445 \mathrm{~cm}^{-1}$ In Ars-AzoTyr were assigned to the azo group $\left(-N^{-} N_{-}\right)$on the basis of $N^{15}$ substitution. The great similarity between the resonance Raman spectra of Ars-AzoTyr and Tetr-AzoTyx can be seen in Table VII. The three major Iines of both spectra occur in the region $1338-1445 \mathrm{~cm}^{-1}$. Substitution of one of the azo group nitrogens of Tetr-Azolyr with $\mathrm{y}^{15}$ resulted in frequency changes for only two peaks. There was a shift from 1388 to $1382 \mathrm{~cm}^{-1}$ and from 1445 to $1438 \mathrm{~cm}^{-1}$. Thus, these two peaks can be assigned to vibrations involving the azo group $\left(-N^{\prime} N-\right)$. This is in agreement with the azo dye, methyl orange, in which Machida et al. (39) assign 1420 and $1395 \mathrm{~cm}^{-1}$ lines to $N=N$ stretches. They also assign the 1155 $\mathrm{cm}^{-1}$ IIne to phenyl-N stretch, but our Iine at $I 149 \mathrm{~cm}^{-1}$ was too wesk and broad to determine if it had shifted.

The substitution of one $\mathrm{N}^{15}$ for $\mathrm{N}^{14}$ in Tetr-AzoTyr would be expected to cause the $N=\mathbb{N}$ vibration to shift $24 \mathrm{~cm}^{-1}$ to Iower frequency. The observed shift was only $7 \mathrm{~cm}^{-1}$. This indicates that the benzene ring contributes to the $-\mathrm{N}=\mathrm{N}$ - vibrations. Similar results were obtained for the $\mathrm{C}-0$ stretching vibration $\left(1250 \mathrm{~cm}^{-1}\right)$ of phenol with $0^{18}$ in place $0^{16}$ in $\mathrm{CCI}_{4}$. Upon substitution, the shift of the $1250 \mathrm{~cm}^{-1}$ band was 6 $\mathrm{cm}^{-1}$ instead of the expected $30 \mathrm{~cm}^{-1}$. This was ascribed to the involvement of the ring in the C-0 vibration (38). 
TABIE VII

PRINCIPAI RAMAN SPECTRAI FREQUENCIES OF ARS-AZOTYR, TETR-AZOTYR, AND N15-TEIR-AZOTYR

Ars-Azo'tyr

( oH 12)

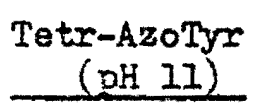

$N^{15}$-Substituted ${ }^{b}$

Tetr-AzoTyx

Assignment

1338 (m)

1342 (10)

(pH II)

1342 (10)

Ring mode?c

1385 (m)

1388 (10)

1382 (10)

$N=N$ stretch

1440 (s)

$1445(10)$

$1438(7)$

$N=N$ streteh $d$

a. The spectra were obtained with $488.0 \mathrm{~nm}$ excitation. The strongest peak was arbitrarlly set equal to 10 for Tetr-AzoTyr. For ArsAzoTyr no sulfate internal standard was used and intensities are denoted by $(s)$, strong and $(m)$, medium. Froquencies are in $\mathrm{cm}^{-1}$.

b. The diazo reagent was prepared from $\mathrm{NaN}^{15} \mathrm{O}_{2}$ and 5 -amino-IH-tetrazole. In Tetr-AzoTyr the labeled nitrogen is attached to the tyrosine ring (see Figure 1).

c. Jakobsen (37).

d. Machida et al. (39). 
In Table VIII, the Raman spectra of 5-diazo-iH-Tetrazole (DHT) and several forms of Tetr-AzoTyr are compared. The pH 11.0 form of TetrAzoTyr and the zinc complex of Tetr-AzoTyx (pH 9.0) are almost identical except for the position of the peak at $1345 \mathrm{~cm}^{-1}$ and in the relative intensities of the peaks at 1345,1389 and $1443 \mathrm{~cm}^{-1}$. From Table Ix one can see that both Tetr-AzoTyr $(\mathrm{pH} 11.0)$ and the zinc complex of TetrAzoTyx have maximum intensity enhancements close to their absorption bands (ca. $500 \mathrm{~nm}$ ). A theoretical calculation based on the equation below (7) show that both Tetr-AzoTyr ( $\mathrm{pH}$ 11.0) and the zinc complex have the expected pattern of intensity enhancements for a chromophore having an absorption maximum at $490 \mathrm{~nm}$ (Table IX).

$$
F_{A}=\frac{\left(V_{0}-\Delta V\right)^{2}\left(V_{e}^{2}+\nu_{0}^{2}\right)}{\left(V_{e}^{2}-V_{0}^{2}\right)^{2}}
$$

where $V_{0}=$ Incident frequency .

$\Delta\rangle=$ Observed Raman shift

$\gamma_{e}=$ Electronic state responsible for resonance enhancement

$\mathrm{F}_{\mathrm{A}}{ }^{2}$ is proportional to the intensity of the Raman peak.

The Raman spectrum of the pH 6.0 form of Tetr-AzoTyr (Table VIII)

shows some differences from the high pH spectrum of Tetr-AzoTyr. It has new peaks at 1401,1470 and $1494 \mathrm{~cm}^{-1}$. The peak at $1438 \mathrm{~cm}^{-1}$ is at a lower frequency in the $\mathrm{pH} 6.0$ form. The peak at $1351 \mathrm{~cm}^{-1}$ corresponds more closely to the peak at $1352 \mathrm{~cm}^{-1}$ in the zinc complex than to the peak at $1345 \mathrm{~cm}^{-1}$ in the $\mathrm{pH} 11.0$ form. The Iow $\mathrm{pH}$ form of Tetr-AzoTyx has maximum resonance with the $457.9 \mathrm{~nm}$ excitation (Table IX) rather than with the $514.5 \mathrm{~nm}$ excltation which was observed with the high ph forms of Tetr-AzoTyr. This is to be expected since the absorption maximum for the pH 6.0 form of Tetr-AzoTyr is at $400 \mathrm{~nm}$. 
TABLE VIII

RAMAN SPECTRAL FREQUENCIES OP DHT AND TETR-AZOMYR ${ }^{2}$

DHT

Tetr-AzoTyr

Tetr-AzoTyr

(DH 6)

(pis 6)

$1142(2)$

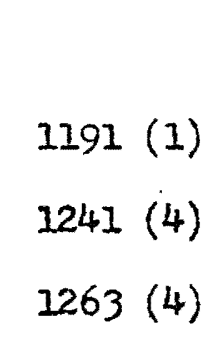

(pH II)

1149 (2)

1187 (1)

1242 (3)

1260 (2)

$1273(2)$

1355 (2)

$\begin{array}{ll}1351(8) & 1345(10) \\ 1386(6) & 1389(10) \\ 1401(6) & \end{array}$

1443 (10)

$1443(7)$

1425 (2)

$1478(10)$

$1438(10)$

1470 (4)

1494 (2)

a. Excitation at $514.5 \mathrm{~nm}$. Frequencies in $\mathrm{cm}^{-1}$. The intensity of the strongest peak was set equal to 10. 
TABLE IX

INTENSITIES OF SELECTED RAMAN FREQUENCIES OF AZO COMPOUIDS AS A FUNCTION OF EXCITATION LINE

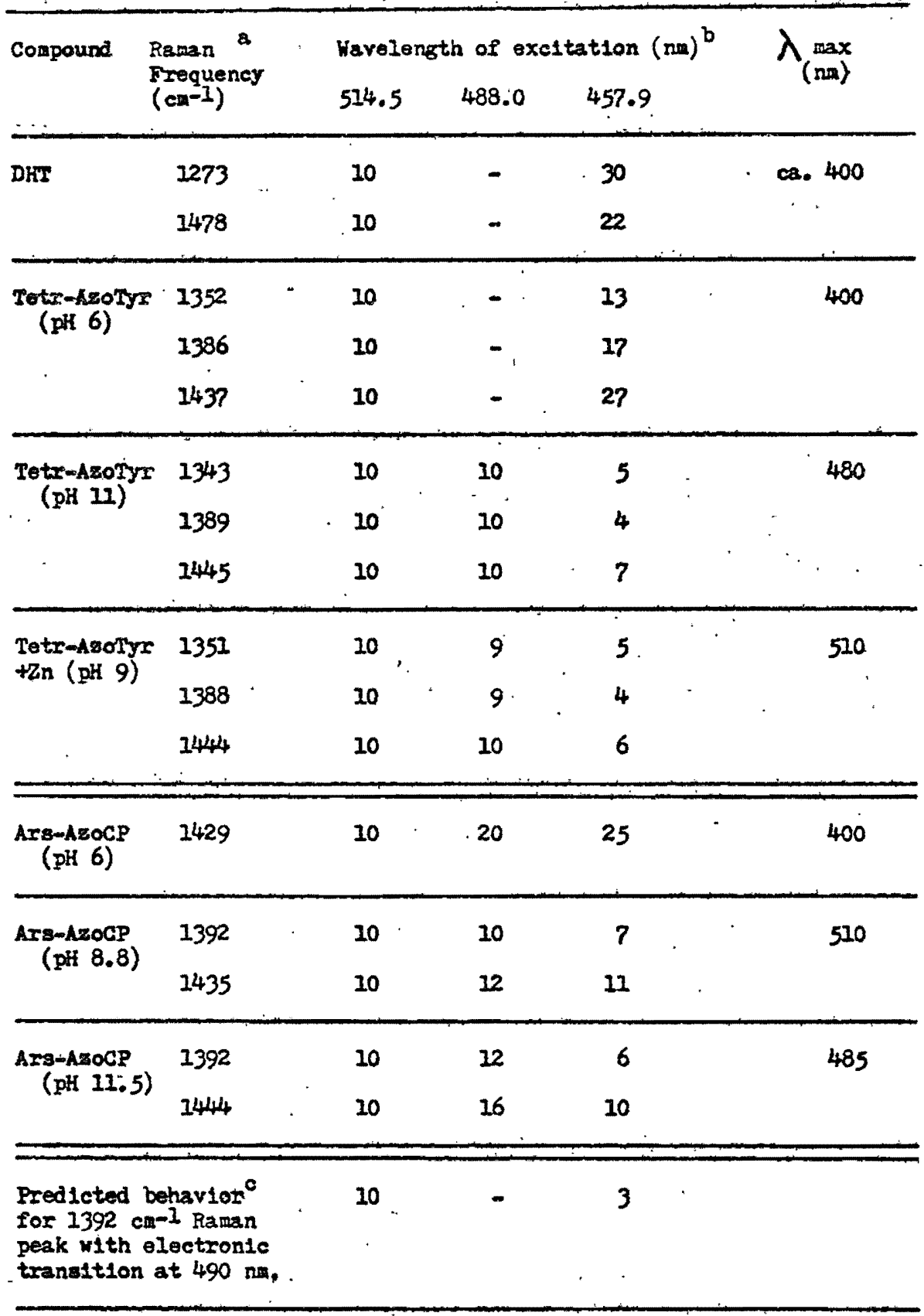

a. Peak frequency was the average of the peak positions obteined with the different excitation wavelengths.

b. For each frequency, the peak intensity at excitation of $514.5 \mathrm{~nm}$ was arbitrarily set equal to 10 .

c. Theoretical calculation based on derlvation of Albrecht and hutloy (7). 


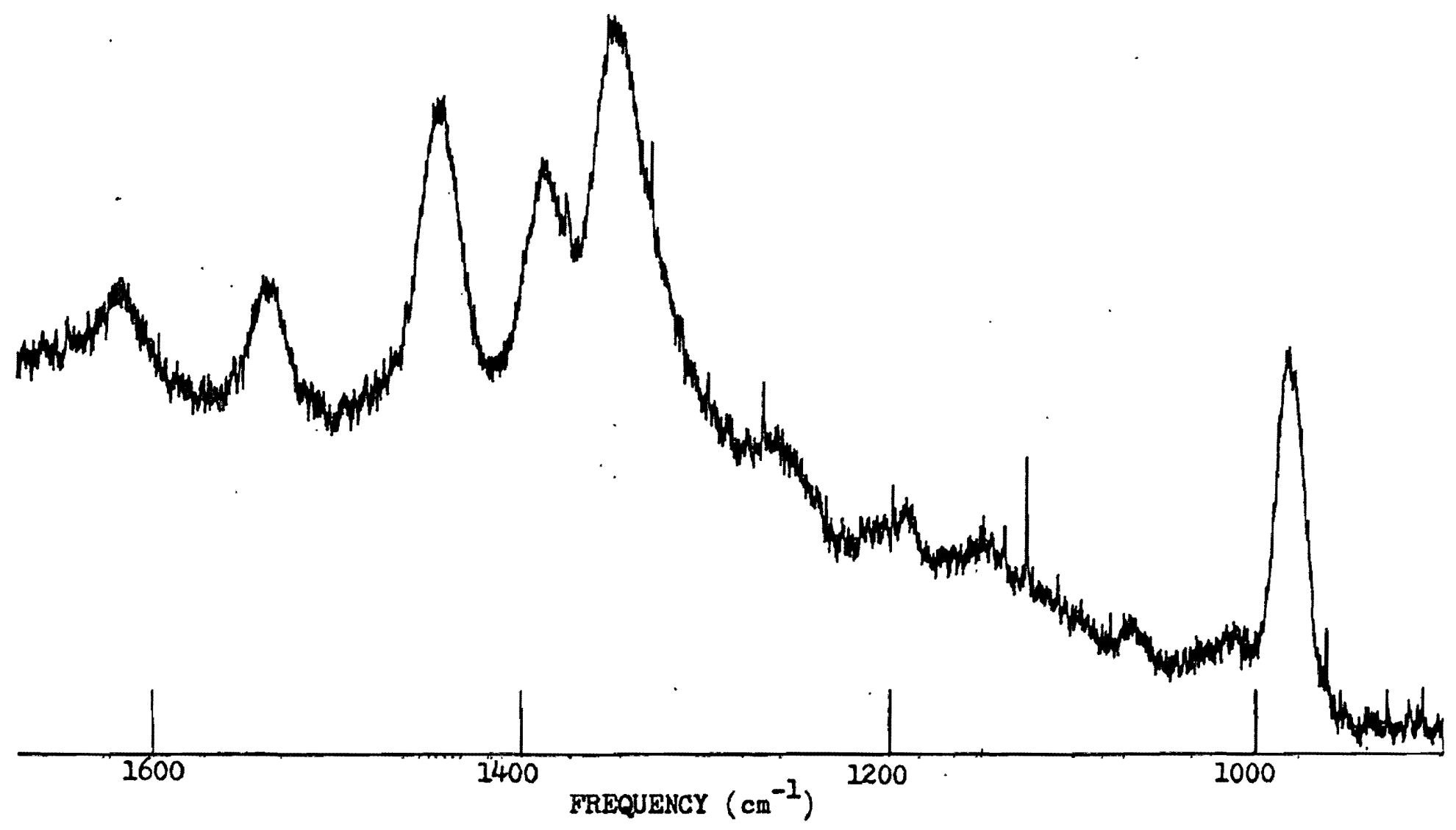

Figure 2. Raman spectrum of $\mathrm{Zn}$ (II)-Tetr-AzoTyr (pH 9.0) at $488.0 \mathrm{~nm}$ exc1tation. 


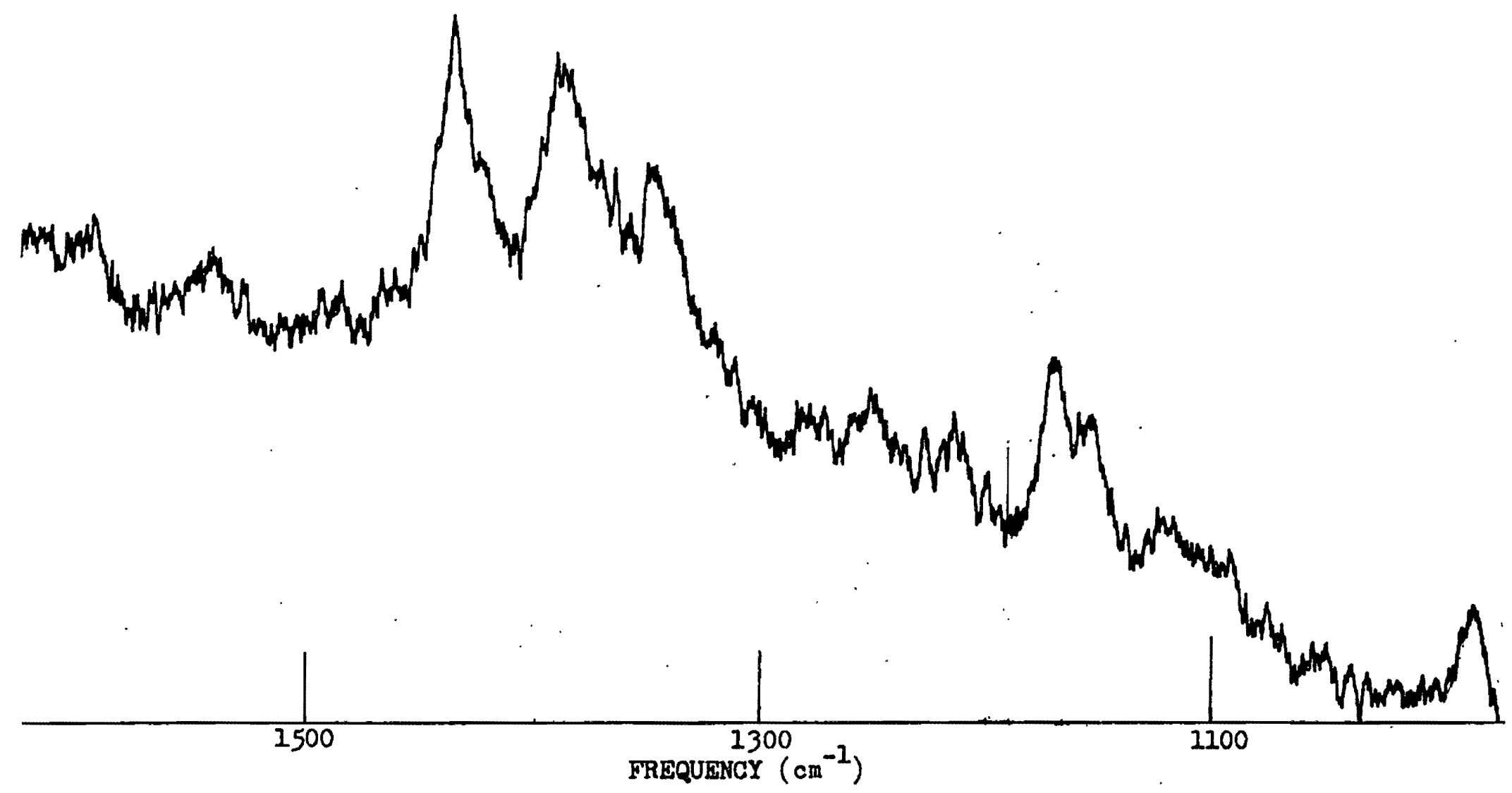

Figure 3. Raman spectrum of $N^{15}-\mathrm{Ars}-\mathrm{AzOCP}$ (pH 8.8) at $488.0 \mathrm{~nm}$ excitation. 
$1432-1442 \mathrm{~cm}^{-1}$ (Table X). This peak is lawer in the pH 8.8 and $\mathrm{pH} 6$ forms (1435 and $1432 \mathrm{~cm}^{-1}$ ) than in the pH 11.5 form $\left(1442 \mathrm{~cm}^{-1}\right)$. The $1345 \mathrm{~cm}^{-1}$ line is too broad to assign its position accurately. Substitution of $\mathrm{N}^{15}$ for $\mathrm{N}^{14}$ in Ars-AzoCP (Table X) causes the peaks at 1390 and $1440 \mathrm{~cm}^{-1}$ to shift to Iower frequencies and identifies these peaks as -N=N-vibrations. This is similar to the shifts observed for TetrAzoTyr (Table VII). 
TABLE X

RAMAN SPECTRAL FREQUENCIES OF ARS-AZOCP AND $\mathrm{N}^{15}$-ARS-AZOCP

\begin{tabular}{ccc|cc}
\multicolumn{2}{c}{} & \multicolumn{2}{c}{$\mathrm{N}^{14}$-Ars-AzoCP } & \multicolumn{2}{c}{$\mathrm{N}^{15}$-Ars-AzOCP b } \\
\hline $\mathrm{pH} 6.0$ & $\mathrm{pH} 8.8$ & $\mathrm{pH} \mathrm{11.5}$ & $\mathrm{pH} 8.8$ & $\mathrm{pH} 11.5$ \\
\hline$(1345)$ & $(1345)$ & $(1345)$ & $(1343)$ & $(1350)$ \\
$1389(10)$ & $1394(10)$ & $1392(10)$ & $1383(10)$ & $1383(10)$ \\
$1432(14)$ & $1435(14)$ & $1442(13)$ & $1430(10)$ & $1433(10)$ \\
\hline
\end{tabular}

a. The intensity of the peak at $1380-1390 \mathrm{~cm}^{-1}$ was axbitrarily set equal to 10. Excitation at $488.0 \mathrm{~nm}$.

b. The diazo reagent was prepared from $\mathrm{NaN}^{15} \mathrm{O}_{2}$ and arsanilic acid. 


\section{DISCUSSION}

\section{Cobalt-Substituted Enzymes}

Colalt-substituted carboxypeptidase and carbonic anhydrase were chosen as candidates for resonance Raman spectroscopy because they possess visible absorption spectra due to the Co(II)-protein complex. Since histidine provides two and three cobalt ligands, respectively, it was hoped that the visible absorption spectra would be due to the Co(II)-histidine chromophore as well as $\operatorname{Co}($ II) d-d transitions.

Studies of model Co(II)-Imidazole and Co(II)-histidine complexes show that although Raman intensities were low, there was a small amount of resonance enhancement associated with a $250 \mathrm{~nm}$ charge-transfer band in the ultraviolet for tetrahedral cobalt-imidazole and with a $560 \mathrm{~nm}$ absorption band in the visible for tetrahedral cobalt-histidine (40). The peaks most susceptible to resonance enhancement were imidazole ring modes at 1165,1210 and $1255 \mathrm{~cm}^{-1}$. In these spectra, the total enhancement was only three-fold, where enhancement is defined as the ratio of sulfate standard concentration to sample concentration required for equal Raman peak intensities. In more favorable cases the enhancement could be 1,000 fold (heme proteins) to 10,000 fold (carotenoids). The lack of resonance enhancement was ascribed to lack of much involvement of ligand orbitals (charge transfer) in the electronic transitions giving rise to visible and ultraviolet absorption. Thus, resonance enhancement of Iigand vibrations was not observed.

In the case of the cobalt-substituted enzymes, we found no evidence 
of resonance-enhanced peaks with excitation near the visible absorption bands $(514.5 \mathrm{~nm})$ or closer to the ultraviolet $(457.9 \mathrm{~nm})$. Although our spectra were not of high quality, we would have been able to observe enhancements of 10 fold or greater. In this respect, the cobalt-substituted zinc enzymes appear to be similar to the model cobalt complexes. Cobalt-substituted carbonic anhydrase and carboxypeptidase also have absorption spectra, magnetic properties, and crystal structures similar to those of tetrahedral low spin Co(II) complexes (2).

\section{Azotyrosine Compounds}

All the azotyrosine-compounds that we made are similar to each other. AlI these compounds have resonance Raman spectra in which tha three major peaks lie in the range $1340-1450 \mathrm{~cm}^{-1}$. An examination of these peaks in the model system can tell us something about the protein arsanilazocarboxypeptidase.

In the pH range studied ( $\mathrm{pH}$ 6.0-11.5) the tetrazole and carboxylate moieties of Tetra-AzoTyr remain unchanged; the amino group ionization at pif 9 should have little effect as this is probably not part of the chromophore. The observed spectral changes which are related to the ionization state of the azo phenol molety have been charactertzed by Johansen and Vallee (18). Tetr-AzoTyr and Ars-AzoCP have similar titration curves. Tetr-AzoTyr has a pK of 9.0 for azo phenol ionization. The zinc complex of Tetr-AzoTyx has two $\mathrm{pK}$ values of approximately 7.0 for zinc complexation and concomitant loss of a proton and 9.5 for dissociation of zinc and azophenolate. Thus, Tetr-AzoTyr is protonated at pH 6.0 and ionized at pH 11.0. The zine complex of Tetr-AzoTyr is at a maximal concentration at $\mathrm{pH}$ 9.0. Apoarsanilazocarboxypeptidase has a pK of 9.4. Arsanilazocarboxypeptidase has two $\mathrm{pK}$ values $(7.7$ and 9.5$)$, one for the formation 
and one for the destruction of the zinc azotyr-248 complex (18). Thus, azotyr -248 is protonated at $\mathrm{pH} 6.0$ and ionized at pH 11.0 . At pH 8.8 , the zinc azotyx-248 complex is at a maximal concentration.

There are at least two possible places of protonation on the azophenol moiety of Tetr-AzoTyr: either the phenoxy group or the nitrogen double bond that links the two rings togethex. Protonation of the nitrogen double bond that. Iinks the two rings would destroy the aromaticity of the benzene ring and result in a quinoid type structure:

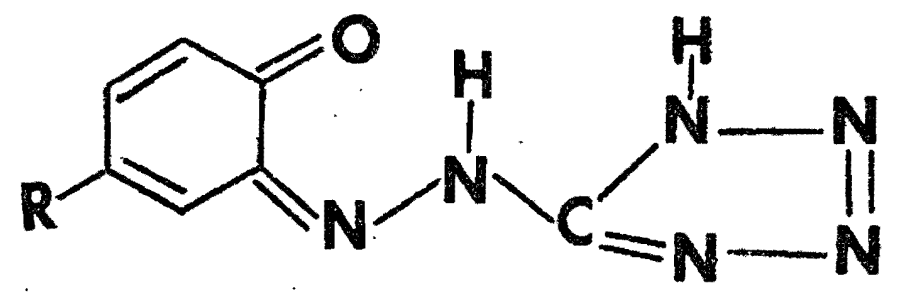

Such a marked change in structure would be expected to give rise to a change in the Raman spectrum. Indeed this does occur in many azo dyes such as methyl orange. The resonance Raman spectrum of methyl orange changes greatly upon protonation. The peaks at 1420 and $1395 \mathrm{~cm}^{-1}$ which have been ascribed to $N=N$ stretch vanish and a new peak at $1183 \mathrm{~cm}^{-I}$ due to $N-N$ appears (39). This is proof that a quinoid structure is formed:

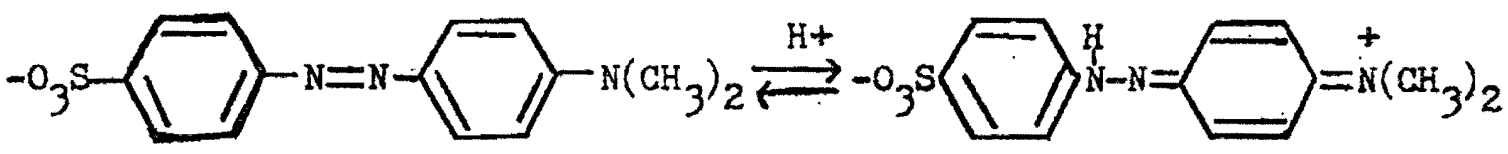

However, when Tetr-AzoTyr is protonated, there is no loss in the peaks that we assigned to $N=N$ vibrations at 1445 and $1389 \mathrm{~cm}^{-1}$ (Table VIII) and no new band near $1183 \mathrm{~cm}^{-1}$. But there is a shift in the position of the peak from 1444 to $1437 \mathrm{~cm}^{-1}$. There is also a shift in the position of a peak at 1343 to $1352 \mathrm{~cm}^{-1}$. It seens Iikely that this latter peak is due 
to the tyrosyl group since this peak was unaffected by $\mathrm{N}^{15}$ substitution and yet it is involved with the protonation of Tetr-AzoTyr. Thus, it appears that the phenoxy group of the Tetr-AzoTyr (Iow pH) is protonated. It also seems probable that there is hydrogen bonding between the hydroxyl group of Tetr-AzoTyr and the nitrogen double bond that IInks the rings together, since the $N=N$ vibration $\left(1445 \mathrm{~cm}^{-1}\right.$ ) is affected. This would result in a thermodynamically favorable six-membered ring:

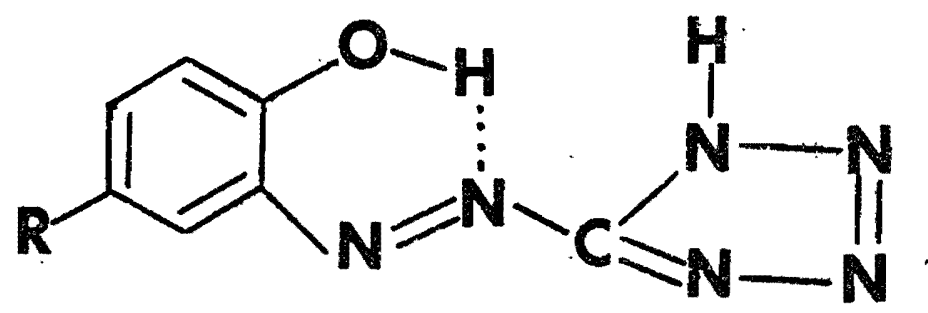

In the zinc complex of Tetr-Azotyr the peak for the tyrosine ring vibration is at $1352 \mathrm{~cm}^{-1}$ (Table VIII). This makes it similar to the low $\mathrm{pH}$ form of Tetr-AzoTyr. But the positions of the peaks assigned to the $N=N$ group ( 1445 and $1389 \mathrm{~cm}^{-1}$ ) are the same as in the high $\mathrm{pH}$ form of Tetr-AzoTyx. Thus, zinc appears to affect the $N=N$ group very little. This implies that there is only a bond formed between the zinc atom and the phenoxy group to Tetr-AzoTyr.

\section{Arsantlazocarboxypeptidase}

In contrast to the zinc complex of Tetr-AzoTyr, the ph 8.8 form of Ars-AzOCP has its $N=N$ peak at $1435 \mathrm{~cm}^{-1}$ whlch is lower than the value of $1442 \mathrm{~cm}^{-1}$ in the $\mathrm{pH} 11.5$ form of the enzyme (Table $\mathrm{x}$ ). The Iow value of the $1435 \mathrm{~cm}^{-1}$ peak is similar to that of $1432 \mathrm{~cm}^{-1}$ for the $\mathrm{pH} 6.0$ form of the enzyme, Indicating that the azo group is involved in zinc binding in arsanilazocarboxypeptidase. Although the $1345 \mathrm{~cm}^{-1}$ peak is too broad to assign its exact frequency, it is most Iikely that Ars-AzocP (pH 8.8) has 
a structure similar to the protonated form of Tetr-AzoTyr, a six-membered ring in which the zinc atom is coordinated to both the phenoxy group and the nitrogen double bond. Thus, the protonated form of Tetr-Azofyr appears to be a batter structural model than the zine compound for the pH 8.8 form of Ars-AzocP.

The involvement of $z$ inc in a six-membered ring in Ars-AzoCP implies that the zinc atom is five-coordinate, since it has three protein ligands ( $2 \mathrm{His}$ and $\mathrm{I} \mathrm{GIu)} \mathrm{in} \mathrm{addition} \mathrm{to} \mathrm{the} \mathrm{two} \mathrm{to} \mathrm{arotyrosine.} \mathrm{Such} \mathrm{a} \mathrm{coordin-}$ ation geonetry appears to be quite feasible for the motal atom in carboxypeptidase. Cokalt-substituted carboxypeptidase appears to be fivecoordinate on the basis of magnetic and spectral properties (41).

Yet one must wonder if this is an adequate model of carboxypeptidase since the presence of the azo group may have altered the structure of the enzyne. By putting the azo group in the protein we have set up the protein for formation of a thermodynamically favorable six-membered ring. Thus, we must question the physiological significance of the modifled carboxypeptidase and whether or not zine is bound to Tyr-248 in the native form of the enzyme.

The $\mathrm{pH}$ of intestinal juice varies from 7.0 to 8.0 (42). The pK value for formation of a zine complex of Ars-AzoCP is 7.7 and maximum complex formation occurs at $\mathrm{pH} 8.8$; the $\mathrm{pK}$ for dissociation of zinc is 9.5 (18). In Ars-AzoCP from which the zine has been removed, Tyx-248 has a $\mathrm{pK}$ of 9.4. Thus, diazotization of tyrosine lowers its pK. value which is normally close to 10.0 . This means that in the native enzyme the $\mathrm{pK}$ for complexation with zine is probably greater than 7.7 and there is less chance for Tyr-248 to bind to the zine atom in the physiological pH range of 7.0 to 8.0 . At the pH optimus of the reaction which is 7.5 (43), 
no more than $20 \%$ of the Tyr-248 at the active site would be bound to $z$ inc. In the proposed reaction sequence for peptide hydrolysis by carboxypeptidase (Figure 4), the protonated form of Tyr-248 is believed to be important in initiating the reaction (4).

Although zinc does not appear to be complexed with Tyr-248 in the active form of carboxypeptidase at $\mathrm{pH} 7.5$, the demonstration that the zinc can complex with Tyx-248 at higher $\mathrm{pH}$ values has interesting structural implications. The carboxypeptidase crystals which were used in the $X$-ray structure determination have a yellow colox when Tyr-248 is diazotized (18). The crystal structure of the unreacted enzyme indicates that Tyr-248 is $17 \&$ away from the einc aton and that the substrate must induce a conformational change in the protein in order for Tyr-248 to move in towards the active site (4). However, when yellow crystals of ArsAzoCP are dissolved without a change in pH they turn red. Thus, it is Iikely that in the native state of carboxypeptidase, Tyx-248 and $z$ inc are considerably closer to one another than in the crystalline state. 
(a)

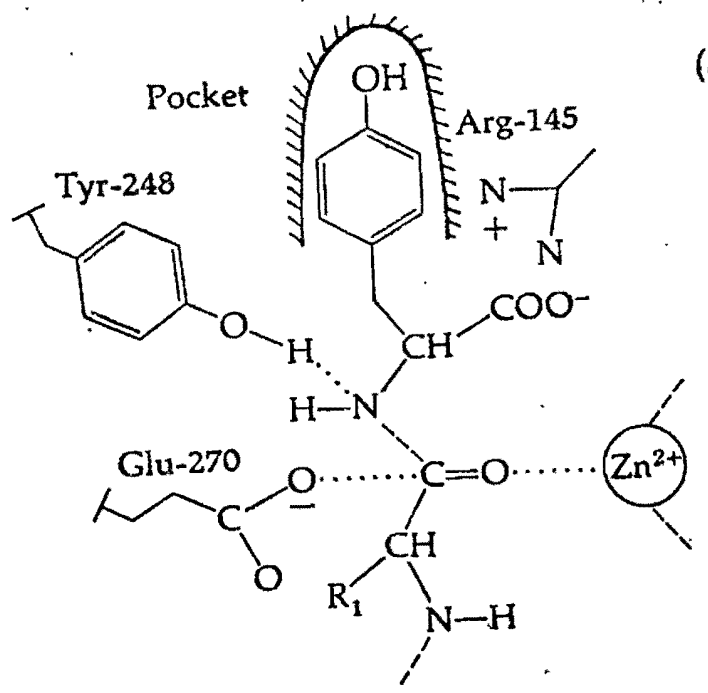

(b)

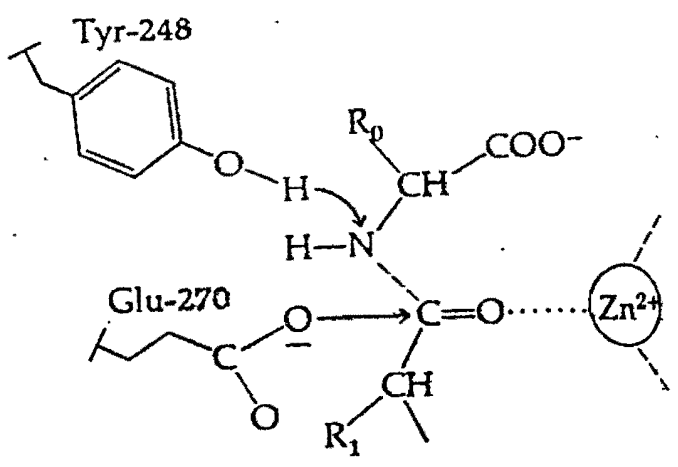

(c)

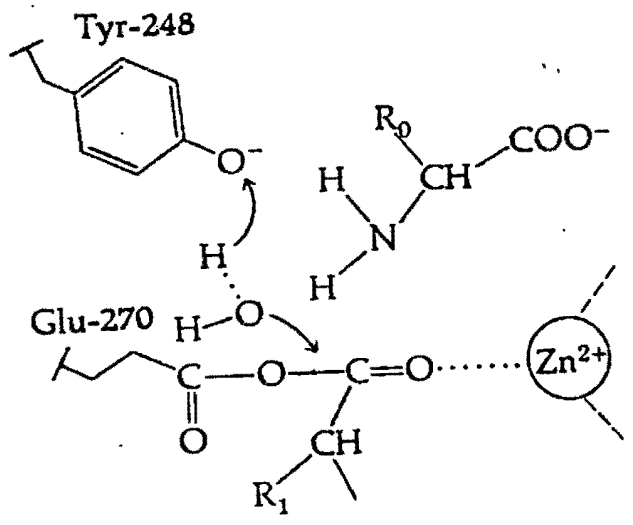

(d)

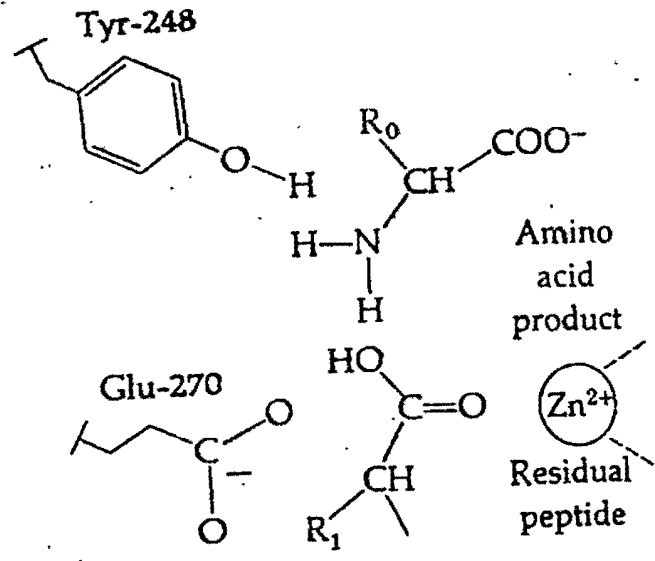

Figure 4. Proposed mechantsm of action of carboxypeptidase.

a. Tyr -248 acts as proton donor to susceptible bond of substrate.

b. The carboxylate oxygen of Glu-270 attacks the carbonyl of the peptide bond with the zinc atom assisting by polarizing the carbonyl group. This results in a tetrahedral intermediate. Breakdown of the tetrahedral intermediate is assisted by the donation of a proton from Tyr-248. The C-terminal amino acid is released. c. The resulting acyl-enzyme is attacked by water with the assistance of the phenolate moiety of Tyr-248. d. This frees the polypeptide chain of the substrate being hydrolyzed.

Figure taken from reference 44 , page 274. 


\section{REFERENCES}

1. Gray, C. J., Enzyme Catalyzed Reactions, Van Nostrand-Relnhold, Iondon (1971).

2. Iindskog, S., Structure and Eonding, 8, 153 (1970).

3. Iiljas, A., K. K. Kannan, P.-C. Bergsten, I. Waara, K. Fridborg, B. Strandberg, U. Carlicom, I. Jarup, S. Lovgren, and M. Petef, Nat. Nex Biol., 235, 131 (1972).

4. Lipscomb, W. N., Accts, of Chem. Res., 2, 81 (1970).

5. Booth, M. R., and R. J. Gillespie, Endeavour, 29, 89 (1970).

6. Behringer, J., Paman Spectroscopy, H. A. Szymanski, Ed. Plenum Press, N. Y., VoI. I, p. 168 (1967).

7. Albrecht, A. C., and M. C. Hutley, J. Chem. Phys, 52, 4438 (1971).

8. Yamanoto, T., G. PaImer, D. Gill, I. T. SaImeen, and I, Rima1, J. Biol. Che日., 248, 5211 (1973).

9. Spiro, T. G., and T. C. Strekas, J. Amer. Chem. Soc., 96, 338 (1974).

10. Loehr, J. S., T. B. Freedman, and T. M. Ioehr, Blochem. Blophys. Res. Commun., 56, 510 (1974).

11. Long, T. V. II, T. M. Loehr, J. R. Allkins, and W. Lovenberg, J. Amer. Chem. Soc., 23, 1809 (1971).

12. Iatt, S. A., and B. I. Vallee, Blochemlstyy, 10, 4263 (1971).

13. Lindskog, S., and A. Ehrenberg, J. Mol. B101., 24, 133 (1967).

14. Kagan, H. M., and B. I. Vallee, Biochemistxy, 8, 4223 (1969).

15. Johansen, J. T., and B. I. Vallee, Proc. Nat. Acad. Sc1., 68, 2532 (1971).

16. Anson, M. I., J. Gen. Physiol., 20,663 (1937).

17. Allan, B. J., P. J. Keller, and K. Neurath, Blochenistry, 2, 40 (1964).

18. Johansen, J. T., and B. I. Valleo, Pxoce Nat. Acad. Scl. 20 , 2006 (1973). 
19. Folk, J. E., and E. W. Schirmer, J. Biol. Chem., 233, 3884 (1963).

20. Wilber, K. M., and N. G. Anderson, J. Biol. Chem., 176, 147 (1248).

21. Worthington Enzyme Manual, Worthington Biochemical Corporation, New Jersey, p. 117 (1972).

22. Lindskog, S., B10chin. Biophys, Acta, 39, 218 (1960).

23. Coleman, J. E., Biochemistry, 4, 2644 (1965).

24. Iindskog, S., J. B101. Chem,, 238, 945 (1963).

25. Vallee, B. I., J. A. Rupley, T. I. Coombs, and H. Neurath, J. Biol. Chem. $235,64(1960)$.

26. Fairclough, G. F., Jr., and B. L. Vallee, Blochemistry, 2, 4087 (1970).

27. Tabachnick, M., and H. Sobotka, J. B102. Chem., 234, 1726 (1959).

28. Johansen, J. T., D. M. Livingston, and B. L. Vallee, Blochemistry, 11, 2584 (I972).

29. Sokolovsky, M., and B. L. Vallee, Blochemiatry, 5, 3574 (1966).

30. Lindskog, S., and B. G. Malmstrom, J. B10I. Chem., 237, 1129 (1962).

31. Lord, R. C., and N.-T. Yu, I. Mol. B101., 50, 509 (1970).

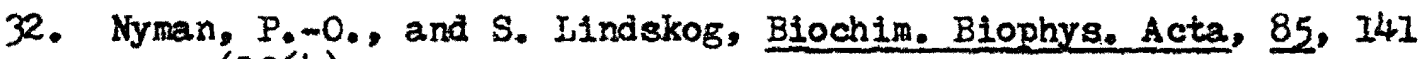
(1964).

33. Tabachnick, M., and H. Sobotik, J. Biol. Chem., 235, 1051 (1960).

34. Cox, D. J., F. C. Bovard, J.-P. Bargetzi, K. A. Walsh, and H. Neurath, Blochemistry, 3, 44 (1964).

35. Pettit, I. D., and D. Turner, Spectrochin. Acta, 24A, 999 (2968).

36. Pinchas, S., D. Sadeh, D. Samuel, J. Phys. Chem., 69, 2259 (1965).

37. Jakobsen, R. J., Spectochim. Act2, 2I, 433 (1965).

38. Pinchas, S., Spectrochim. Acta, 28A, 801 (1972).

39. Machids, K., B. -K. KIm, Y. Sa1to, K. Igarashi, T. Uno, BulI. Chem. Soc. Japan, 47, $78(1974)$.

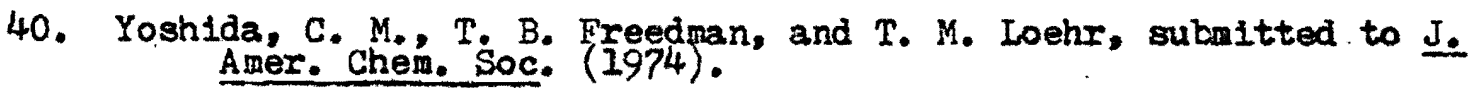


42. Rosenberg, R. C., C. A. Root, R.-H. Wang, M. Cerdonio, and H. B. Gray, Proc. Nat. Acad. Sc1., 70, 161 (1973).

42. West, E. S., and H. R. Todd, Textbook of Blochenistry, Macmilian Company, New York (1962).

43. Quischo, F. A., and W. N. Lipscomb, Advances in Protein Chemistry, 25, 1 (1971).

44. White, A., P. Handler, and E. I. Smith, Pxincloles of Biochemistry, MeGraw-H11I, New York (1973). 